\title{
SAUDI STANCE ON POTENTIAL IRANIAN THREAT IN THE MIDDLE EAST
}

\author{
* Muhammad Abdul Mughis Irfan Siddeqi, \\ Research Scholar, Federal Urdu University, Karachi. (mughisirfan@ yahoo.com)
}

\begin{abstract}
This study examines the Saudis foreign policy towards Iran and the situation in Middle East due to Saudis proxies in Syria, Bahrain and Yemen. It also seeks the growing Iranian influence and interest in Middle East causing a sense of unrest for Gulf States. This article also encompasses the factors under which great Sunni alliance has been formed and the Saudis attempt to isolate Iran at least in the Islamic world. This article is conceptual in nature as it relies to a large extent on secondary sources of data i.e Print and electronic media. It also throws light on the current situation in Middle East and the religious, ideological, geostrategic concerns and geopolitical rivalry of two great nations i.e of Iran and Saudis. This paper also discusses the Saudis expectations from the west and particularly from America and growing ties of Iran with America and the west. It also highlights on silent character of Israel and the rising threat of ISIS in Middle East.
\end{abstract}

KEYWORDS: Middle East, Iran, Saudis, Syria, Gulf.

\section{INTRODUCTION}

This study examines the Saudis foreign policy towards Iran and the situation in Middle East due to Saudis proxies in Syria, Bahrain and Yemen. It also seeks the growing Iranian influence and interest in Middle East causing a sense of unrest for Gulf States. This article also encompasses the factors under which great Sunni alliance has been formed and the Saudis attempt to isolate Iran at least in the Islamic world. This article is conceptual in nature as it relies to a large extent on secondary sources of data i.e Print and electronic media. It also throws light on the current situation in Middle East and the religious, ideological, geostrategic concerns and geopolitical rivalry of two great nations i.e of Iran and Saudis. This paper also discusses the Saudis expectations from the west and particularly from America and growing ties of Iran with America and 
the west. It also highlights on silent character of Israel and the rising threat of ISIS in Middle East.

We live in a globalized age of mass interaction where dependency and relevancy is no longer pertinent to individual nations, rather a conglomerate of nations divided into whole areas that dictate and shape interests and events throughout the globe. Perhaps one of the most complex and influential regions of the world is the Middle East; a land ridden with tumultuous relations between inhabiting countries and long abated histories that have shaped said intricacies. If summed up the current state of affairs depicts a constant power play in the region that is rich in natural resources and consequentially has geo-political ramifications. However this is just the tip of the iceberg.

Over the years there are two relevant but certainly not exclusive events that have played sizeable parts in shaping the current situation of the Middle East. These events have certainly bred a crisis that is both deeply rooted and cerebral at the very least - meaning it will take just as many years, if not more, to come to reasonable terms as it has taken to set these scenarios into motion.

Bilateral diplomatic relations between Kingdom of Saudi Arabia and Islamic Republic of Iran in contemporary years have been portrayed by religious, ideological conflicts, contesting geopolitical and geo strategic concerns and progressing rivalry for territorial hegemony with the rise of the Arab Spring. The rivalry between the two oily rich nations has been increased manifold in recent times, particularly due to geopolitical, religious and sectarian situations of Syria, Bahrain and Yemen which have brought the two nations of Islamic world to lock their horns on many issues.

The recent revolutionary Arab Spring in the Arab World have been perceived by the monarchs of Arabian world, a potential danger to their monarchies and hegemonies in general and Saudis in particular. (Paul, 2009) The Saudis also consider it a potential danger and growing influence of Iran in the Arab World. This thing has been widely realized by the Saudis and other Arab countries. Now Saudis foreign diplomatic policy has changed from passivity to aggressiveness. The Saudis are going for new Inter Arab Alliance to counter the Iranian i.e Shia threats and influences in the Arab World and especially in the Shia population of the Gulf States. Moreover, Saudis are also trying to establish a broad Sunni 
Alliance outside the Gulf in Islamic world to counter the growing threat of Iranian desire to gain the political interests in Arab Shia population in the Gulf.

With the start of the 2011, Arabian Spring or we may call it new Arab Revolutionary Wave, the Saudis who always played a role as a pro status quo and conservative territorial power in the Arab world, though sometimes it acted as a revolutionary force and sometimes also played the role of counter revolutionary force depending upon the situations and their rational interest. The finest example in this regard, is when we see heavily involvement of Saudi Arabia in Yemen crises and its actively participation in toppling the President Ali Abdullah Saleh Regime in Yemen. Saudis also had a significant role in formulating a territorial political buttress for external interference in Libya against Qadhfi's government and ousting his govt which ultimately resulted in his brutal murder. But on the other side, we see that Saudis are supporting at their level best by employing their arm forces to crush nationwide protest of Iran backed Shia population of tiny Gulf state of Bahrain and to stand side by side the Al Khalifa Regime and providing all out support to keep the Regime of present Bahraini Sunni monarch in place. Similarly, the Saudis also supported Mubarak government in Egypt against Muslim Brotherhood and later General Abdul Fateh Sisi's military Regime, who overthrew the democratic elected government of Ikhwan's President Muhammad Mursi. Here we see a contrast in Saudis foreign policy. On one side Saudis are supporting counter revolutionary forces in case of Egypt and Bahrain and on other side they are supporting opponents of President Bashar-al-Asad. The Saudis want to oust the minority $10 \%$ of Alwhites who are ruling over Sunni majority of $88 \%$ in Syria. (Nasser, 2013)

These gripping differences and disparities of Saudi foreign policies show that Saudis are doing at all levels to counter Iran in every possible way. Now Saudis are considering Iran, the major political and security danger in the Arab World due to many reasons. The Saudis have serious reservations about Iran's growing desire to show its presence in Gulf. They have also a vigilant eye on Iran's hot pursuit for nuclear capability which could endanger and threaten the Saudis role as a territorial power in the region. Saudis also believe that the getting of military might and influence of Iran would also have a negative influence from Saudis point of view on OPEC and Shias of Arabian Peninsula and to some extent the Muslim Brotherhood and other religious Sunni organizations as well. (Vali, 2006) 


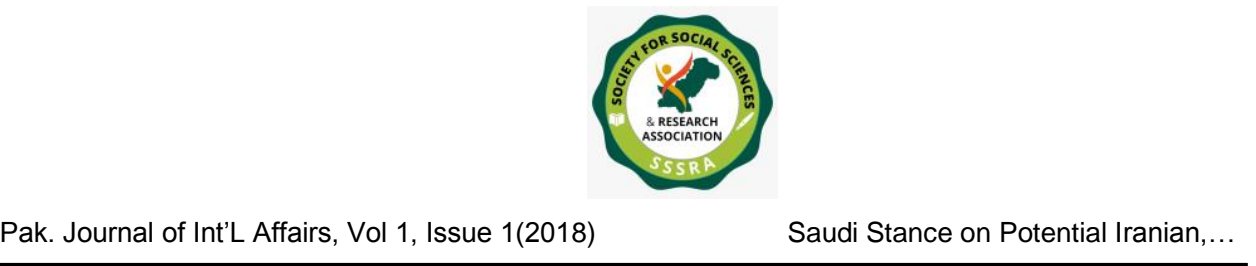

The recent political and security dispute between KSA and Iran is based mostly on sectarian grounds, both the countries belong to two different schools of religious thoughts of Islam. Iran is Shia dominating having $20 \%$ of Sunni populations while in Saudi Arabia Sunnis are in majority while Shia population is $15 \%$ in Saudi Arabia. Both the countries claim of Islamic legitimacy of Islamic authority ironically and both the Muslim countries are not ready to accept each other's Islam and school of thought.

This converging state of intense religious, ideological, sectarian and historical contentions with aggravating and conflicting geostrategic, geopolitical interests give us a clear picture of Iranian and the Saudi strategy and bilateral interests in war torn Syria and ultimately further division and fueling sectarianism in the Arabian Peninsula.

\section{SAUDIS ACTIVE INTERFERENCE IN SYRIAN CONFLICT}

Syria had been once an ally of Saudis in near past but these relations took U-turn when Assad Regime violently suppressed the peaceful political processions in Syria, which started in March 2011. Which later turn into civil conflicts. This situation forced Saudis to change their policy and to stand by the majority Sunni population who was protesting to oust the minority ruling class. This situation created a gap between two countries. The situation further aggravated when Prime Minster Rafiq-ul Hariri of Lebanon, who was a staunch supporter of Saudis in the region was assassinated in 2005. The Saudis saw a linkage of Iran and Syria in the assassination of Rafiq-ul Hariri. This assassination proved to be a crucial and turning point in the policy of Saudis towards Syria. Despite all these development, the Syria-Saudi communications over the formula of a national united government in Lebanon continued with low graded official relations. But never be upgraded to a sound political alliance as Saudis always sought Iranian and Syrian relations a Shia Alliance and an alliance against Saudis and to the very existence of Salafis Islam.

This prevailing thought between the two countries i.e Syria and KSA made the diplomatic relations cooled off. The widespread political protests by the majority Sunni Syrian against the minority, ruling Alvites i.e the Asad Regime violently crushing of these protests by the Syrian 


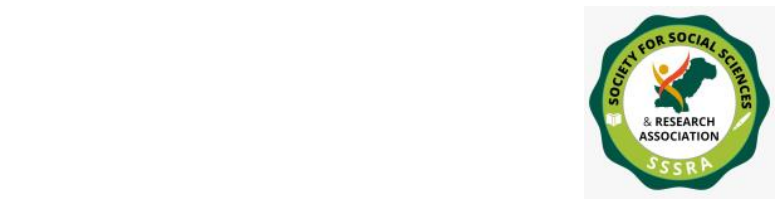

Pak. Journal of Int'L Affairs, Vol 1, Issue 1(2018)

Saudi Stance on Potential Iranian, ...

Army and added more fuel to already burning fire between the two Arab countries. The unrest in Syria continued to grow further and the Assad military's brutality in tackling the situation made Saudi Arabia to condemn the brutalities and atrocities and to call back its ambassador from Damascus in August 2011.

The Saudis strong opposition to Assad Regime and strong buttress in terms of military and moral support to repress and crack down on Iran backed Shia uprising are the clear proof that the Saudis are forming a strong Alliance of Sunnis to stand up against increasing Iranian social and political advances in Arab World. Saudis are of in the opinion that they would reduce Iranian influence if they topple Assad or Alvite's Government in Syria and ultimately weaken the might of the "Shia Axis". Saudis are adamant and acting consistently against Shia advancements, together with other Gulf States. The Saudis has taken Joint action against Syrian and Iranian Alliance. Syrian membership in Arab league has also been suspended due to Gulf countries initiative. All GCC countries are supplying uninterruptedly financial and military aid to fighting forces of Syrian Opposition i.e free Syrian Army. (See, 2015)

The Saudis have adopted an approach that's more assertive and more forceful then the past and are trying to establish new alliances in the territory identical to its own interests. Actually, Saudis and its Allies has chosen a distinctive approach of offensive contesting. Saudis expected a lot from United States, their historical ally to buttress the free Syrian Army against Asad Regime, are now intensely feeling bitter for United States who did not help the anti-Assad opposition as per the Saudis expectations or made any effort to weaken the Assad and Iran or Shia Allies in the region. (Joby, 2015)

When Saudis failed to get the desired response from United States. they decided to come forward and to act a prominent role in this situation. Saudis decided, due to their deep rooted and traditional rich Sunni Islamic Character, to assume a prominent role in the region. Another reason behind this was that Saudis attempted in distancing Assad's Government from the emerging Shia Alliance led by Iran had been completely failed. The resistance in Syria and strong rebellion against Alvites provoked Saudis to build a new bearer against Iranian Influence in the region by ousting Assad's Regime. (Elizabeth, 2013) 
The GCC countries lead by Saudi Arabia adopted a resilient stand in 2011 in that they demanded from Syria to cease "deadly suppression of citizen's by the Syrian Army headed by Assad's regime King Abdulllah also demanded that Syria must "stop the killing machine" The Alvite minority government of Assad did not pay ahead to this Saudi King warning. This led the GCC to put their all-out efforts to support Syrian Opposition and the warring parties and to shut the doors of Iranian i.e Shia's influence which could tip the regional balance of power in favour of Iran. (Adrian, 2011)

The critics are in the view that Iran is going towards solitary in the Muslim World by fighting everyone. Azerbaijan, another Shia country with $97 \%$ Shia population vigorously supported Saudi stance on Yemen and also became the part of great Muslim Alliance, Here, it is pertinent to mention here that Iran's strategic stake in Yemen is not as high as it is in Syria. But Saudis are always doubtful about Iran's stake. In Gulf, Saudis take it seriously by referring high ranked Iranian official who proudly claimed about his country's control over four Arab states, Lebanon, Syria, Iraq and Yemen. It is an open secret of Iran's policy and Iranian dangerous designs on Yemen. (Doyle, 2015) Jamal Khashoggi, (Prominent Saudis political commentator says that it would be very difficult for Saudis to accept Iranian hegemony over Yemen, Syria or Bahrain. It is pertinent to mention here that Iran has not supported Houthis as it supported Syrians and Iraqi Shias by active participation of Islamic Revolutionary Guard Corps (IRGC) in Iraq and Syria. Iran is only supporting Houthis by means of weapons and finance. Saudis think that though Iran has made "a very small investment in the Houthis and reaped a large political return. Here we see that Houthis Shias who are very close to Sunnis and have good relations with Sunnis as compared to hardliner twelvers Shias, are pushed due to Saudis fear into the Iranian camp. It is also feared by the Saudis that Iran want from Saudi Arabia to concede Syria and Iraq in exchange for Iran abandoning out Orins its support for the Houthis.. (Karim, 2014)

It is quite evident that all GCC countries are fully supporting by all means to all rebel groups for the anti-Iranian cause. By overthrowing Assad Regime is a first and foremost policy of Saudi foreign policy. Saudis are not just aiding by material and financial support but also providing to boast the political oppositions to Assad i.e National Coalition for Syrian Revolutionary and Opposition Forces. 
Since March 2014 Saudis officially are not funding radical segment of the Syrian Opposition to Assad. They have designated both AlNusra Front and ISIS as terrorist groups. The Saudis are suspicious of ISIS although belonging to Salafi sect, because ISIS openly announces Gulf's ruling monarchs as illegal. This is also another rising and emerging problem for Saudis. (Mehran, 2014)

The increasing sectarianism, joining of Jihadis to ISIS are very worrisome for Saudis. Now they are also trying to crush ISIS within their borders with an iron hand. In 2014, about 200 Saudis had been arrested accuse of ISIS members on charges of assassination and targeting military and government installations.

Saudis are also calling for International diplomatic and economic pressure on Assad's Regime. The Saudi led coalition tried to convince USA against Assad when his regime used chemical weapons in 2013. They also persuade Obama Administration that by using chemical weapons the Syrian army had crossed the redline set by USA and that this action of Assad's Regime had no other option except strong military action in response to such violation.

The wall street journal in its report in Feb 2013, has mentioned that the Saudi Secret Intelligence Agency gave proof of use of mass level of chemical weapon by Asad Regime. But American silence or American reluctance in active participation in Syria issue have raised many doubts about Saudis main ally and main defense provider to deliver. American policy of staying out of the Syrian issue has frustrated all of its GCC allies particularly Saudi king. US policy in case of Syria i.e physically nonintervention in Syria and the reconcilement with Iran infuriated American's Gulf allies who have given a clear cut message saying that USA's reliability is on the stake if it let present Syrian Regime be victorious in the war. (Assad, 2013)

The more robust regional influence of Saudis can also be seen in the political atmosphere of Lebanon where Saudis has invested hugely both economically and politically. Saudi 03 billion huge investment and aid to the Armed forces of Lebanon has also annoyed Hezbullah, who considers this an attempt of Saudis to be debilitate organizational base of Hezbullah and its asset. (Anna, 2014). Hezbullah also see Saudis interference in Lebanon as a potential threat to its strength and its political position in Lebanon. Although Saudis and Iranians are striping to architect 


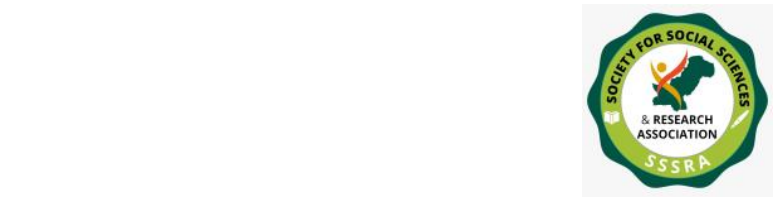

the balance of authority in the region using mutual incitement and psychological warfare by means of media and financing of internal and external opponents and proxies. Iran is using its influence on the 15\% percent Shia population of Saudi Arabia while Saudis too are now establishing links with Arab minority in Khuzestan, Baluchis of Sistan and other Sunnis faction which make the $20 \%$ percent of the Iranian population. (Herman, 2014)

The situation has been further aggravated due to permanent agreement of Iran and the West and American. Saudis see this agreement as to strengthen Iran's position in the territory. Saudis also consider a serious setback about American's Iran rapprochement and analyze it as USA further disengagement from the region. Saudis perceived Iranian threat, worsening situation of unrest and chaos in war torn Iraq is making Iran in a position of grand bargain "with US as both countries are coming on common grounds by giving US a solid reason to strengthen its ties with Iran.

Seeing the cold behavior of its great and once trusted ally i.e the US, the Saudis are now looking towards other options. Saudis in December 2015, announced 34 Islamic countries military alliance to combat menace of terrorism, led by Saudi Arabia with a headquarter in Riyadh to cater the perceived Iranian threats and to isolate the Iran. This military alliance should be called an alliance of Sunni countries who see Iranian support to Assad Regime, Bahrain Shia opposition and Yemen. Houthis purely based on sectarian and Iranian hegemony and nefarious designs in the region. In an announcement given after the formation of this military alliance which state "a duty to protect the Islamic nations from the evils of all terrorist groups and organizations whatever their sect and name which wreak death and corruption on earth and aim to terrorize the innocent "(Reuters- Dec 15). The coalition force is expected to fight all terrorist groups in the region. In other words, it would be quite appropriate to say that this Sunni force will be fighting against the Shia force and Shia regional power and to some extent with Sunni terrorist groups as well.

\section{SAUDI'S STANCE ON BAHRAIN}

The Arab Spring also affected Bahraini soil. Bahrain sectarian schism forced Iran to come in Bahrain. Initially the protests were for only democratic and political reforms. These protests were generally very 


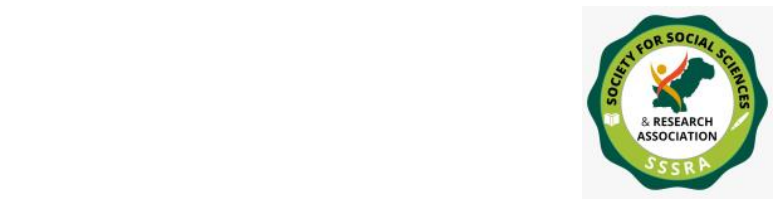

peaceful and even the King was not criticized at any stage in these processions. But with the involvement of Iran and Saudi Arabia's vis-à-vis presence in Bahrain's soil made the situation so vulnerable and later made it Pro-Iranian violent Shia protests. This situation led the arrival of Saudi led GCC troops which later paved the way of open Iran intervention in Bahrain in support of these protests. The physical presence of Saudis troops and other GCC countries troops was also an attempt to prevent the Iranian backed Shia protest who were demanding more, democratic powers. But Saudis considered these protests serious implications for their own internal security. Iran's increasing involvement in the protests in Bahrain coupled with the red line for Saudi Arabia of saving the regime of Al Khalifa and also provided justification for KSA to intervene within Bahrain. The internal situations of Bahrain have an added and enhanced motivation for Saudis and Iran to act while Saudis are mostly concerned about growing influence of Iran backed Shias in Bahrain and its dire consequences for the Eastern Province of Saudi Arabia which has Shia majority. On the other side we see that the situation of Bahrain also gives a chance for Iran to enhance its legitimacy in the region. The Saudis are trying to preserve the Al Khalifa Regime and Iranian are supporting the Shia opposition groups who are demanding the overthrow of minority Sunni Al Khalifa regime which has increased tensions between Riyadh and Tehran.

The presence of $\mathrm{Al}$ Khalifa regime in Bahrain is very important for the territorial security and the internal stability of KSA. That's any Iranian influence in the region has necessitated a severe and hardline response by Saudis. It is obvious that the battle for Bahrain is of prime importance for both the states.

\section{SAUDI'S STANCE ON YEMEN}

The Saudis led military alliance attacked Yemen and Houthis rebels. The GCC and Saudis want to bring in power the Mansor Al Hadi government. Saudis always consider its neighbor Yemen as their backyard. Saudis believe that Iran is backing Houthis, the Yemen's Zaidia Sect, the Fiver Shias and different from mainstream Shias who are twelve, Houthis are fighting alongside Ali Abdullah Saleh, the former Yemeni president. Yemen controlled by Houthis to the north and advancing towards South backed by Iranian Support. The Houthis advancement towards South is a matter of great concern for Saudis who consider this Houthis rise as Iran backed and a potential danger to Saudi Arabia in 
internal strategic security. Saudis believe that Houthi-Iranian proxies, a stance that compels Houthis closer to Iranians. Seeing this Iranian influence on Houthis, Saudis lead effort to isolate the Houthis on all front, put economic sanctions on Houthis, weaken them from military point of view. Houthis also conducted military exercises near Saudis border which further aggravated the Saudis apprehensions regarding influence of Iran in the region. Saudis believe that the troubled Yemen and rise of Houthis would escalate the situation in Saudis Southern Oil rich but Shia majority region. The rise of Houthi rebels is considered by Saudis as the indirect arrival of Iranians armed groups in their Southern Borders. Saudis consider that they are the leading state rather front line state in their war against Iranian territorial expansionism. The scenario in Yemen is pressing very hard for Saudi position against the Houthis who are viewed by the Saudis as Iranian proxies. (Conley Alley, senior Arabian Peninsula analyst for the international crises group). Saudis also fear the rise of Houthis in Yemen as a potential danger and the beginning of the end for their monarchy. The Yemen attack by Saudis is considered as "existential necessary" for Saudis in particular and other Arab countries in general. The bombing of Iran's embassy in Sanaa also bears the witness that Saudis consider Iran as their arch enemy. Similarly, the burning of Saudi Embassy in Tehran by protesters shows that both the states have locked their horns over the issue of Yemen. Mokhtar al-Rabhi, the minister of information in Hadi's cabinet told Reuters that Iranians attack on Saudi Embassy in Tehran had further hardened the stance of Sunni Gulf Arab States and this would lead the other Sunni states of the world to limit their ties with Iran. In this case we see that most of the Islamic countries are backing Saudi Arabia. The fine example in this regard is the establishment of 34 Muslim countries military alliance led by Saudi Arabia.

The Saudis are not determining the exact calculation regarding potential rise of radical groups in Iraq and Syria. There is also a potential threat in the region that these groups can upset a balance between Shia and Sunni faction of the community in the Gulf. In this perceived situation, the most vulnerable countries would be Saudi Arabia itself, then Iraq, Kuwait and Bahrain.

The current stance of Saudis has raised tensions due to over reacting on perceived Iranian threat by anti-Iranian hardliners in Gulf. These hardliners in the region believe that ousting Assad's Government could correct a blockade in front of Iran and "restore Iran to its natural size" and hopefully there would be no further confrontation left after 


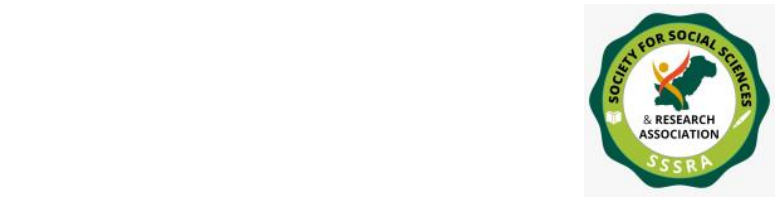

Pak. Journal of Int'L Affairs, Vol 1, Issue 1(2018)

Saudi Stance on Potential Iranian, ...

overthrowing Assad's Regime between Iran and Saudi Arabia. (Adam, 2013)

Some of the analysts in the Gulf believe that huge funding to the opposition group in Syria by Saudis and other Gulf countries for over throwing Syrian government and weakening Iran would not serve the ultimate purpose. These analysts are in the opinion that aggressively investing on their groups would further enhance the extremism and fundamentalism. In the area which would be more dangerous for these countries to tackle these radical group. However, we see that ISIS has become a potential threat for Saudis as well, which is now recruiting new blood globally. Furthermore, they are inviting Jihadis from all over the world in Arab region and have started attacking in Saudis Arabia and other countries in the region. The emergence of ISIS and the anticipated division of Iraq into 3 to 4 ethnic and sectarian states contributed further in deteriorating the existing complicating and perplexed Riyadh-Tehran bilateral relation. Here we see that the Gulf leaders are trying to tackle both the problems at a same time.

\section{CONCLUSION}

The Middle East is a boiling pot of inter-webbed crises which are constantly brewing over the flames of global geopolitics. The land is privileged with vast reserves of Oil that has played as a proponent of causing regional as well as international conflict. In summation the Middle East is a land both blessed and damned at the same time. Regional power houses The Kingdom of Saudi Arabia and The Republic of Iran are constantly locked in a shadow war to claim dominance in the region. This proxy conflict has resulted in the sparking of many regional and even international events that have shaped the World we live in today. On the other side we see the Israel- Palestine debacle. The failure to see a just and peaceful resolution till date is a failure on the international community's part as well as overt callousness exhibited by the rest of the World that is doing nothing to curb the suffering being inflicted on the innocent Palestinians on a routinely basis. Both these deeply entangled issues have sculpted the Middle East region and have sculpted the World we live in today. The impact and importance of the region is prevalent and many a major events have been direct derivatives of these conflicts. Whatever the concern, the Middle East region has and will continue to play an integral role in the geopolitical affairs of the World. While making conclusion we see the change over from Saudi 
King Abdullah to King Salman that has brought a perceptible change in Saudi stance on its foreign policy. Now Saudis have adopted a more aggressive policy to tackle growing Iranian territorial subversion. Here we see that Saudis are pursuing a new policy from Lebanon to Syria and from Yemen to Bahrain. This new Saudi policy is also going against the Middle East polices of USA. The Saudis robust policy is a reaction against America's diplomatic overtures to Iran after the nuclear deal with Iran and America's new geopolitical equilibrium in the region. Under al this situation some questions arise. Are Saudis gaining any success due to their stance in Middle East? Is Iran a real threat for Saudi Arabia? Is Iran physically involved in the matters of Middle East including Syria? Do we think that pro-Iranian forces capable enough to overcome Sunni majority in the Middle East? All answers to these questions will take time except the first one which has the answer that is Saudis have gained Islamic world vast Sunni majority support at least and to some extent isolating the Iran in Middle East. Another success which Saudis can proudly claim is that they have gained the favor of four major Islamic countries who have joined Saudis in the joint military force of 34 countries i.e Turkey, Pakistan, Egypt and Malaysia. While answers of the other questions are yet to be awaited. In short, it can be said that Saudis have at least created a wall against perceived Iranian threat. They have successfully stopped the advances of Houthis on their Yemen border. The Saudis could not gain the desired results in Syria due to Russian and Iranian involvement and backing of Assad Regime. In case of Syria, Saudis have lost their great Ally in case of Syria i.e. the Americans who now believe that Assad Regime can stay in power. However, in foreseeable future, Saudis aggressive and robust policy is likely to endure in case of Syria and other parts of Gulf. The Saudis have also started to consider USA no longer a trustable and dependable ally and going towards Sunni Muslim states. 


\section{REFERENCES}

Adam E.,and Sioban G, (2013) Behind Assad's Comback, a Mismatch in communication. The Wall Street journal, December 31,.

Adrian B., (2011)“Syria unrest: Saudi Arabia calls on killing machine "to stop" the telegraph, August 8,

Anna B.,(2014) Saudis Grant to Lebanon is see as Message to US, The New York Times, January 6.,

Assad A. (2013): Our battle with Saudis is open ended, Al Akhbar, November 30 .

Doyle M., (2015) "Syria and the perils of proxy war, "Las Angeles Times, 2015. Elizabeth D., (2013) "playing with fire: why private Gulf financing for Syria's extremist Rebels Ricks igniting sectarian conflict at Home, "Saban center for middle East policy, Brookings Institution, December 6,.

Herman F.(2014) elitsSaudi Arabia's foreign policy, "Diplomacy in the middle east: the international relations of regional and outside posers, L. C.Brown (ed) (London). 238-40.

Joby W., (2015) "Syrian conflict said to fuel sectarian tensions in Persian Gulf," Wshington past, December 19,

Karim S. (2015) Senior Associate.Carnegic Endowment lard for international peace (Nov).

Mehran K.,(2014) The Arab Spring and the Saudi-led counterrevolution, Orvis, LVI:1, 101-03.

Nasser C., (2013) "Hezbollah escalates rhetoric against Riyadh," Al Monitor, December10,

Paul A., and Joris V. D.,(2009) "Saudi Arabia after US-Iranian détente: Left in the Lurch "Middle East Policy, XVI:13 P 70,

See P. P., (2015)“Iran and Saudi Arabia: Rapprochement on the Horizon? "National Interest, May 15,.

Vali N., (2006) "When the Shiites rise, "foreign Affairs, LXXXV:4, 59. 